\title{
9
}

\section{Romantic Voice: The Hero's Text}

I did not make myself the heroine of my tales. Life appeared to me too common-place an affair as regarded myself. I could not figure to myself that romantic woes or wonderful events would ever be my lot.

$$
\text { -Mary Shelley, Frankenstein }
$$

I am utterly and completely Lélia.

—George SAND, Letter to Sainte-Beuve

Genius has no sex.

-Germaine de StaëL, Letter to Benjamin Constant

When Isabelle de Charrière wrote the Lettres de Mistriss Henley as an immediate response to Le Mari sentimental, she was interrupting the longer novel that would become her best-known work-the Lettres écrites de Lausanne (1785) and its sequel, Caliste, ou suite des lettres écrites de Lausanne (1787). The double title of this novel is no casual choice: it figures deep dualities that critics and readers have usually "resolved" by renaming the entire novel Caliste. The work begins as a series of letters by an anonymous Mme de *** about her daughter Cécile's (economically necessary) foray into the marriage market, but just when a serious and troubling match seems to be developing between Cécile and the Englishman Edouard, this plot is abandoned for a long narrative about the ill-fated love of Edouard's cousin William for a woman he calls Caliste. In this way, a courtship story narrated by a woman turns into a Romantic tragedy narrated by a man.

This split in both story and discourse, underscored by the aban- 
donment of Cécile's history at its moment of greatest intensity, marks a larger turning point in the history of narrative: a displacement of female personal voice that will characterize European fiction for half a century. If the eighteenth-century novel is the "heroine's text," the Romantic novel is even more fully the hero's, ${ }^{1}$ for Romanticism gives new primacy to the singular voice representing the singular (if noncoherent) subject who "holds the center of works whose primary purpose is the presentation of his character." ${ }^{2}$ To the list of novels I named in Chapter 2-Pamela, Clarissa, Moll Flanders, La vie de Marianne, La Religieuse, Julie ou la nouvelle Héloüse, Fanny Hill-European Romanticism counterposes titles like René, Adolphe, Obermann, Die Leiden des jungen Werthers, Hyperion, Heinrich von Ofterdingen, Alastor, La confession d'un enfant du siècle. This narrative masculinization is far more complete than any feminization that preceded it, for while eighteenth-century fiction gave place and voice to male figures from Crusoe, Des Grieux, and Grandison to Tristram Shandy, Humphry Clinker and Valmont, Romanticism's "great myths"-Prometheus, Satan, Faust, Don Juan, Napoleon-are ineluctably male, ${ }^{3}$ and women figure in high Romantic fiction almost entirely as repressed "others" virtually without voice. Femininity is of course routinely bound to the male subject in the Romantic images of the twin and the androgyne, but the central figure in this union remains male; woman is muse, object or servant of the male quest, source of sorrow or ecstasy, at best the man's double, a "narcissistic projection" of himself. ${ }^{4}$ Goethe's Werther, Chauteaubriand's René, Byron's Childe Harold, Musset's Octave, Constant's Adolphe all absorb "feminine" affectivity into "masculine" genius, unconventionality, physical and sexual freedom,

1. I intend here a traditional understanding of "Romanticism" rather than a redefinition that might account for writers and texts of the period from 1780 to the 1830 who are usually excluded from Romantic canonicity. I retain the traditional conception because I see Romanticism as a male-centered movement in which women struggled against severely masculinist biases. See, for example, Margaret Homans, Women Writers and Poetic Identity: Dorothy Wordsworth, Emily Brontë, and Emily Dickinson (Princeton: Princeton University Press, 1981); and Marlon B. Ross, "Romantic Quest and Conquest: Troping Masculine Power in the Crisis of Poetic Identity," in Romanticism and Feminism, ed. Anne K. Mellor (Bloomington: Indiana University Press, 1988), 26-51. On redefining Romanticism, see Stuart Curran, "Romantic Poetry: The I Altered," in Romanticism and Feminism, 185-207, and Marlon Ross, Contours of Masculine Desire: Romanticism and the Rise of Women's Poetry (New York: Oxford University Press, 1989).

2. Lilian Furst, The Contours of European Romanticism (London: Macmillan, 1979), 43.

3. Lloyd Bishop, The Romantic Hero and His Heirs in French Literature (New York: Peter Lang, 1984), 19 .

4. James D. Wilson, The Romantic Heroic Ideal (Baton Rouge: Louisiana State University Press, 1982), 96. See also Leslie Rabine, Reading the Romantic Heroine: Text, History, Ideology (Ann Arbor: The University of Michigan Press, 1985). 
intellectual and spiritual quest ${ }^{5}$ splitting sensibility from domesticity and thus from the heroine's "sphere."

It does not seem impossible that this subsumption of the "feminine" was in some part a reaction to the increasing presence of female voice in fiction, just as male modernism has been considered in part a reaction to women writers at the end of the next century. But whatever the causes of this shift to a male-centered narrative economy, the result is a virtual disappearance from the novel of female personal voice: just when the single narrating subject becomes most insistently the center of narrative, in other words, that subject becomes masculine. ${ }^{6}$ The narrative divide in Charrière's novel tells us that well before René and Adolphe, and before the post-Revolutionary backlash against women writers and intellectuals that I described in Chapter 4 , at least one woman was actively repeating the male-centered personal voice that Werther had employed with such electrifying results. Startlingly, not one of the women (or men) associated with high Romanticism seems ever to have published a novel written exclusively in the female personal voice. While it is crucial to examine this absence novel by novel, the larger pattern is an important sign of the complicated relationship of women to Romantic ideology and especially to Romantic subjectivity. The evidence of narrative voice suggests that Romanticism offered women the lure of the universal, the escape from gender and thus from the always-problematic female body by which a woman's genius, spirituality, and freedom were denied. Yet the strategies for this escape from gender ("genius has no sex") end up signifying its impossibility. I do not see the nonachievement of female autodiegetic voice as a refusal of hegemonic authority or subjectivity, as some postmodernist feminists have argued, but rather as a historically situated struggle with contemporary social values and literary forms. Before I turn to the problematic status of female voice in fiction by the three women novelists most closely identified with European high Romanticism-Germaine de Staël, Mary Shelley, and George Sand-I will look briefly at the Lettres écrites de Lausanne, with the Lettres de Mistriss Henley as a hinge for the novel's two sections, in order to

5. For a recent discussion of this phenomenon, see Margaret Waller, "Cherchez la Femme: Male Malady and Narrative Politics in the French Romantic Novel," PMLA 104 (1989), 14151 .

6. One could argue that formally speaking the heroine's text made the hero's possible, that the interiority Romanticism celebrates is already configured in female voices such as Clarissa's and Julie's. See Alan Richardson, "Romanticism and the Colonization of the Feminine," in Romanticism and Feminism, 13-25. 
suggest why some women might have had a stake in a Romantic flight from female voice.

Recognizably the prototype of Staël's Corinne, Charrière's Caliste is a brilliant and talented artist-performer with a "compromised" past, who has become passionately involved with the Englishman William, for whom duty is stronger-or courage weaker-than love. The opposing force is William's father, who disapproves of his liaison with Caliste; all the more because the father has already suffered deeply from the death of William's twin brother, both Caliste and William resign themselves to loveless marriages. But William's father has a belated change of heart, and ironies pile up until at last the unhappy Caliste succumbs to a consumptive death and William himself falls dangerously ill from grief.

Sold by her own mother first to the London stage and then to the keeping of a "gentleman," Caliste is clearly a victim of a particular sexual and political economy; indeed, the consequences of Mme de ***'s warnings to her daughter Cécile are evident everywhere in Caliste's story, and since Caliste too is well born, one could surmise that but for circumstance and mother-love Cécile could be in Caliste's place. But the novel never acknowledges these similarities. The title notwithstanding, William, and not Caliste, is the center of the narrative: it is occasioned by Mme de ***'s concern for his welfare, it begins with his family history, and except for a final letter from Caliste's husband, it proceeds entirely from his point of view. William's version emphasizes not sexual politics but sensibility in an insensible society; his anguished despair overshadows his responsibility for Caliste's misfortunes, and he comes to seem equally with Caliste a victim of circumstance. His final litany of self-accusation ("I ought to have... I ought to have...") identifies him in Romantically selfaggrandizing language as "the most worthy of his unhappiness,"7 and ultimately it is less Caliste's tragedy than his own that he grieves: "Here I am, then, alone on earth. She who loved me is no more. I hadn't the courage to avert this loss; now I haven't the strength to endure it" (231). Even the final letter from Caliste's husband absolves William, and although there is no further response from Mme de *** in the published volume, in a "suite" found among Charrière's papers the

7. Isabelle de Charrière, Lettres écrites de Lausanne, in Oeuvres complètes (Geneva: Slatkine, 1980), vol. 8, 230. All further references will appear in the text. English translations are my own. 
mother who had been so critical of patriarchy's double standards goes to some length to exonerate William: "If you neglected her you neglected yourself as well" (240).

It is through William's narrative dominance, then, that Caliste's plight, manifestly a function of the gender and class politics that Mme de $* * *$ exposes, gets re-presented as personal fatality, the suffering of the exceptional soul. The longing for death, which in Mistriss Henley was grounded in feminist despair, gets mystified in Caliste, and the gender-specific causes of her tragedy disappear, along with William's own culpability, beneath the twinning of William and Caliste as Romantic suicides. Critics have perpetuated this mystification by treating Caliste as if it were the entire novel rather than a dependent part and by emphasizing in Charrière's fictional philosophy not a feminist protest, but a Wertherian death wish. ${ }^{8}$

Read against Mistriss Henley, however, the unarticulated shift in Lettres écrites de Lausanne from a female voice preoccupied with the material plight of women to a male voice preoccupied with the spiritual plight of "men" becomes less curious. The impasse generated by the courtship plot, vividly dramatized in Mistriss Henley, makes it virtually impossible for Charrière to bring Cécile's story to a happy end: sexual and economic double standards have already structured her relationships as they structure the Henleys' and, as Jean Starobinski points out, Cécile's suitor Edouard resembles his cousin William in loving less completely than the woman wholoves him. ${ }^{9}$ The "Romantic death-wish" that Janine Rossard identifies in Caliste and associates with "the emptiness of the philosophy of happiness at the end of the eighteenth century; the futility of heroic struggle in this same society; and the impotence of reason" ${ }^{10}$ might stem in Caliste, as it clearly does both in Mistriss Henley and in Charrière's own history, from the particular emptiness of an educated woman's restricted life. Nor was Charrière insensitive to the somewhat different futilities of a poor woman's situation: both Lettres neuchâteloises ( 1784 ) and Mistriss Henley represent working-class women as victims of double standards and indeed of sexual abuse.

But since neither the conventions of the novel nor the society on which Charrière depended were amenable to these feminist questions,

8. See especially Janine Rossard, "Le Désir de mort romantique dans Caliste," PMLA 87 (1972), 492-98.

9. Jean Starobinski, cited in Charrière, Oeuvres complètes, vol. 8, 129.

10. Rossard, "Le Désir de mort," 492. Translation mine. 
it is plausible that she might turn to a Wertherian mal du siècle in which gender is recuperated into a "universal" (upper-class) malaise. An unpublished epistolary novel that Charrière began in 1796 makes explicit the attractiveness of a Wertherian ethos as an antidote to feminist anxiety: to Emily's reproaches for her romanticism, Harriet retorts, "is it not much safer to love an imaginary object than an unworthy one? I had in mind to say a real one... There, there, is danger, true danger-As long as I love no body but Werther no dangerous command shall be exerted over me." Although Emily argues, in turn, that "those heroines whose virtues are but paper and ink may be what they please.... Let them have fifty children about them they will not suffer of the head ach [sic]," and although Charrière's writings of the 1790 sill suggest a return to a materialist ideology, becoming "Werthered" and 'Romanticated" in the mid- 1780 os allowed Charrière to avoid confronting men as oppressors and to join with them in their quest for the Ideal. ${ }^{11}$

A crucially placed passage in the Lettres écrites de Lausanne demonstrates dramatically this slide from the specific and material to the generic and spiritual. Having nursed a black man dying in the neighborhood, Cécile acknowledges, if with some equivocation, the tragic dimensions of colonialism and slavery: "So this is how one ends, Mama... ?What a strange lot! to be born in Guinea, to be sold by one's parents, to plant sugar in Jamaica, to serve the English in London, to die near Lausanne! ... This poor Negro!" [Quel étrange sort! naître en Guinée, être vendu par ses parens, cultiver du sucre à la Jamaïque, servir des Anglois à Londres, mourir près de Lausanne! ... Ce pauvre nègre!] (187). But she immediately "corrects" herself: "But why say this poor Negro? To die in one's own country or elsewhere, to have lived a long time or a little, to have had more or less trouble or pleasure-there comes a moment when none of this matters: the King of France will be like this Negro one day." [Mais pourquoi dire ce pauvre nègre? mourir dans son pays ou auilleurs, avoir vécu long-temps ou peu de temps, avoir eu un peu plus ou un peumoins de peine ou de plaisir, il vient un moment où cela est bien égal: le Roi de France sera un jour comme ce nègre.] (187). If the king will be like the slave, then no revolution, no material change, no protest, is needed: in death, social imbalance will equalize itself. Here is the legitimation for Charrière's reconciliation with the status quo, her 
choice of Enlightenment idealism over the incipient materialism of Revolutionary ideology. If idealism could have served social interests by arguing that the slave and the king must have nothing more or less than equal rights, here a Romantic fatalism turns away from such an opportunity.

It seems therefore extremely significant that this isolated and apparently gratuitous episode of the dying man appears at just the moment when the novel will abandon Cécile's history for the fatal story of Caliste. For the entire Lettres écrites de Lausanne repeats the gesture of this episode: while it begins with the specific and political, it ends with the generic and metaphysical, "Romanticating" a woman's material life. What enables this transformation, I believe, is the shift to male voice, the voice of "universal" suffering, which offers Charrière a distance from the feminist impasse her works repeatedly inscribe. At the very least, Caliste was able to escape the controversies generated by all three of Charrière's earlier published fictions and to place her in a less embattled avant-garde: it is no accident that her best-known and most-loved work is the Caliste section of the Lettres écrites de Lausanne.

Yet I will argue that this refuge that generic Romanticism seemed to offer women was also illusory: women could never fully exploit the radical potential of Romantic ideology because the "human" was not the "female." The Romantic woman's "splendid" escape from the body and the body politic into transcendence was, as Margaret Homans also argues, repeatedly undermined or thwarted by Romanticism's double messages. ${ }^{12}$ By the turn of the nineteenth century, the association of Romantic subjectivity with male voice had solidified so that constructing a female "Romantic hero" demanded a double overturning of Romantic norms: the displacement of male subjectivity from center to periphery, and the transformation of plot to allow the tropes of Romantic questing a plausible female form. It is these historically situated literary conditions, rather than any antiauthoritarian "feminine" or even feminist refusal of voice, that I believe are responsible for the forms of women's Romantic narratives.

One result is that most women writing from 1790 to 1830 simply did not participate actively in the creation of (what has passed for) Romantic fiction. Jane Austen might be said to have created a Romantic subject in Anne Elliot, who is Persuasion's superior and sen- 
sitive, lonely and misunderstood outsider-protagonist, but Anne's longings are always tempered by social morality and are ultimately circumscribed by the marriage quest, and she is not given the utter centrality of personal voice. Other women writers simply repeated the male Romantic text. Beneath its deceptive title, for example, Barbara de Krüdener's Valérie (1803) is little more than a reproduction of Werther: Gustave, hopelessly in love with the married Valérie, is at once the heroic character and the narrating voice, while the loved object who gives her name to the novel is a nearly silent figurehead. Charlotte Smith's authorial novel The Old Manor House (1793) also creates a Romantic protagonist in the adventurer and sometime poet Orlando, whose cherished Monimia is little more than his passive double.

I want to turn, however, to the three novelists who do seem to have attempted, at separate moments across three decades, to create female counterparts to the Romantic hero's text. Staël, Shelley, and Sand were all deeply involved both with Romantic thought and with men who were constructing the kind of subject-centered narratives that I have been describing. Each of these women wrote a novel in which a woman is a Romantic hero, but none of them-nor, to my knowledge, any woman writing Romantically before the 1840 - - ever published a novel written exclusively in the female hero's voice. Corinne, Lélia, and Mathilda off er different, autobiographically resonant configurations for female subjectivity that together sketch in the particular resistances of high Romanticism to female voice.

It is difficult to overestimate the historical impact of Staël's Corinne, ou l'Italie (1807) in figuring the woman of genius. Undoubtedly and indeed disturbingly indebted to Caliste, ${ }^{13}$ the novel constructs its female hero's inner life in ways that Charrière's novel does not approach. From her first "Improvisation at the Capitol" to her "Last Song," Corinne's public speeches and private writings are represented by the authorial narrator (as William almost never represents Caliste's) and at midtext Corinne and Oswald narrate their personal histories. Yet from the beginning the novel's dominant focalizing consciousness is Oswald's; Corinne is seen first and last through his perspective, and although her thoughts are also represented, Oswald's constitute the

13. On the "disturbingly strong resemblances" between Corinne and Caliste see Madelyn Gutwirth, Madame de Staël, Novelist: The Emergence of the Artist as Woman (Urbana: University of Illinois Press, 1978), 165-66. Gutwirth considers it "lucky" that Charrière died the year before Corinne appeared, "or else she might have felt that not only her lover [Benjamin Constant], but her novel as well had been appropriated by her rival." 
framing subjectivity. These narrative practices not only distance the female Romantic hero from her creator but authorize Corinne through the perspectives of men. Indeed, the text uses an entire community of voices to prepare for the introduction of Corinne as "a goddess amid the clouds," superiority as a "refined sensitive woman ... with no one to turn to but herself" (338). When the narrator explains that "it is impossible for a woman living independently to be pleased with herself" (129), she may be hinting that the extraordinary woman is never in a position to authorize her own exceptionality. Corinne is thus given the status of Romantic hero but not fully of Romantic subject: hers is the prophetic voice and vision in the text without being the prophetic voice and vision of the text.

I am not suggesting that Corinne "ought" to have been the novel's narrator or even its dominant focalizing consciousness, or that the work was ever intended to be written otherwise, but I do want to point to the difference between the narrative representation of firstgeneration Romanticism's most heralded female figure and the figures of such male counterparts as Werther, René, and Adolphe. It is understandable that Staël would adopt an authorial voice for this novel, for as its double title suggests, Corinne, ou l'Italie is almost as much the study of a culture as of a character: the work is replete with extensive discussions of literature, history, and art. Yet it is also possible that this broader design was imposed precisely to keep Corinne from "hold[ing] the center" of the text: according to Avriel Goldberger, Simone Balayé's research reveals three complete revisions of Corinne that suggest Staël "worked to put a distance between her own life and the world of her novel" (for example, by giving Oswald some of her own history). ${ }^{15}$ Marie-Claire Vallois hails Corinne's narrative structure as a fortunate "escape" from "the trap of autobiography, the ritual of confidence and penitence performed by an 'I,' which imprisons once and for all-the trap of the 'I' that could only repeat, as Napoleon would have it, that anatomy is destiny."16 If Staël did find autobiography a "trap," might this have been because her society would indeed have used the novel to entrap her? As my discussion

\footnotetext{
14. Germaine de Staël, Corinne, or Italy, trans. Avriel Goldberger (New Brunswick, N.J.: Rutgers University Press, 1987), 21 . All further references will appear in the text.

15. Avriel Goldberger, introduction to Corinne, or Italy, lii.

16. Marie-Claire Vallois, "Voice as Fossil: Madame de Staël's Corinne or Italy: An Archaeology of Feminine Discourse," Tulsa Studies in Women's Literature 6 (Spring 1987): 50.
} 
of Shelley's and Sand's Romantic fictions will make clearer, I find it significant that Vallois sees the female body as the obstacle to personal voice.

Corinne stands, then, as both a sign and a legacy. As a sign, it suggests that the female heroic subject is more easily a thematic than a formal center of narrative; as the most famous "first-generation" construction of female Romantic identity read avidly by both Mary Shelley and George Sand and influential on women writers for decades to come, Corinne patterns a formal separation of the female hero from the text's narrative voice and sustains the distinction between female and male Romantic fictions that I have been describing. Shelley's unpublished novel Mathilda (1819-20), on the other hand, does reproduce the Romantic pattern of a single personal voice. I will propose that Mathilda was made possible for Shelley by the writing of Frankenstein, and that the failure of Mathilda to be published is not unrelated to the problems of constructing Romantic heroism in female terms.

In its surface manifestations, of course, Frankenstein (1818) shares none of the gynocentric impulses of Corinne or even Caliste: it is virtually a caricature of Romantic male-centeredness. Mrs. Saville, the empty signifier toward which the narrative supposedly directs itself, ${ }^{17}$ well represents the place of female subjectivity in this novel: women are peripheral and almost interchangeable figures readily sacrificed to male pursuits, of fering tenuous links to a domestic community that most of the male characters claim to honor but repeatedly reject. Except for two letters written by Elizabeth, women's voices figure significantly only on the occasion of Justine's trial, and the result simply underscores their impotence: Elizabeth's words further condemn the woman she is trying to save, and Justine's false confession seals her doom. Despite its array of female characters, then, Rosemary Graham is right to call Frankenstein a novel "about a world without women"; it is no wonder that readers were shocked that a woman had authored it. ${ }^{18}$ Indeed, the novel is so blatantly male-Romantic

17. For a more positive reading of Mrs. Saville's "emptiness," see Gayatri Chakravorty Spivak, "Three Women's Texts and a Critique of Imperialism," in "Race," Writing, and Difference, ed. Henry Louis Gates, Jr. (Chicago: University of Chicago Press, 1986), 278.

18. Rosemary Graham, "For Want of a Wife: The Influence of Mary Wollstonecraft's Vindication of the Rights of Woman on Mary Shelley's Frankenstein," unpublished paper written at the University of Virginia. Graham notes that Frankenstein does not even protect Elizabeth's life because he is so certain that the Creature's warning is a threat against his life and not hers. 
that it provides a grudging Harold Bloom with "one of the most vivid versions we have of the Romantic mythology of the self" despite or because of its "flaws." ${ }^{19}$ Frankenstein has now become one of the novels most fully subjected to feminist scrutiny, and I do not wish here to enter the debates about the ways in which it is or is not a "woman's book. ${ }^{, 20}$ I can see the possibility of a subversive reading of Frankenstein as antiheroic and even antimasculine, but I agree with Mary Poovey and Robert Kiely that the novel ultimately valorizes Frankenstein more than it undermines him and that the self-ironizing of its voices serves conventional, self-authorizing purposes. Read against other Romantic narratives, in other words, Frankenstein does not stand out as a critique of the tradition in which it takes part. ${ }^{21}$

Rather than argue for the female in Frankenstein, I prefer to suggest that the very "maleness" of the novel allowed Shelley to move toward female voice by working out in "universal" or "generic" space genderspecific anxieties about authorship and autobiography, imitation and originality. Frankenstein assumes, as this chapter's epigraph from its preface suggests, that Romantic heroism and Romantic writing are male projects, and inscribes a woman's desire for authority in a repeating structure of male voice that may have been superimposed upon the novel's original design. Precisely because it represents the exaggerated inefficacy of female voice and the exaggerated potency of male voice, I believe Frankenstein permitted Shelley to write out male Romanticism and to move on in her next novel to a femalecentered narrative about a different kind of parentally created "monstrosity." In other words and to exaggerate somewhat, Frankenstein is

19. Bloom's ad feminam afterword to the Signet edition claims that precisely "because it lacks the sophistication and imaginative complexity" of Manfred and Prometheus Unbound, Frankenstein "affords a unique introduction to the archetypal world of the Romantics" (New York: New American Library, 1965), 215.

20. See especially Sandra Gilbert and Susan Gubar, The Madwoman in the Attic (New Haven: Yale University Press, 1979), 213-47; Barbara Johnson, "My Monster/My Self," Diacritics 12 (1982): 2-10; Mary Jacobus, "Is There a Woman in This Text?" New Literary History $14(1982)$ : $117-41$; and Devon Hodges, "Frankenstein and the Feminine Subversion of the Novel," Tulsa Studies in Women's Literature 2 (Fall 1983): $155^{-64}$.

21. I am disagreeing here with Devon Hodges' claim that Shelley's use of multiple narrators "undermines the stability of the male voice" through its aberrant narrative practices ("Frankenstein and Feminine Subversion," 157). I agree rather with Robert Kiely that Frankenstein uses relatively conventional Romantic narrative strategies; see The Romantic Novel in England (Cambridge: Harvard University Press, 1972). However, Frankenstein might lend itself to an esoteric feminist rereading if one reads as gendered rather than generic its many negative uses of the word "man" (see xi, 88, 114,137 ). 
not only, as Barbara Johnson says, a novel about the writing of Frankenstein, ${ }^{22}$ it is a novel about the writing of Mathilda, the then-unwritten story of a woman's "romantic woes."

Shelley's nervously self-centered $183^{1}$ preface provides a link with each of Frankenstein's narrators and narratees. Beginning with Mrs. Saville, whose "feminine" position is mirrored in Shelley's description of herself as a "devout and nearly silent listener" to the conversations of men, ${ }^{23}$ the narrative agents of Frankenstein become vehicles for exploring Shelley's isolation in a male literary world, her fears of both eccentricity and conformity, of creating but also of failing to create the "unbidden"-forbidden?-tale. To paraphrase Gilbert and Gubar speaking of Eve, ${ }^{24}$ the part of Shelley is all the parts: Walton is the author reduced to copyist, Frankenstein the author whose creative dreams have gone awry, and the Creature a text whose voice, if not yet female, is also not humanly male.

As critics note repeatedly, by naming her novel a "hideous progeny" Shelley has begged readers to see her alliance with Victor Frankenstein, who is also terrified by his "odious handiwork" (54). Frankenstein is indeed the ultimate innovator, creating what was supposed to be a copy (of a man) but what turns out to be an aesthetically unacceptable product, entirely without precedent (if, arguably, but the incarnation of Frankenstein's own grotesque soul). Shelley, the devotee striving for acceptability, likewise ends up with a wholly original novel that does not "owe the suggestion of one incident, nor scarcely of one train of feeling" (xi) to Percy Shelley or to anyone-not even, as Anne Mellor perceptively notices, to the conventional sources in folklore and legend from which other Romantic mythmakers drew their ideas. ${ }^{25}$ It is precisely this originality that I believe is mitigated by the framing device of epistolarity. If we take the preface to be accurate on this score, the first words Shelley thought of were Frankenstein's - that sentence about the "dreary night in November" that now constitutes the beginning of Chapter 5. On Percy's "incitement," says Shelley, she turned a short tale into a novel and created "the

22. Johnson, "My Monster/My Self," 7.

23. Mary Shelley, Frankenstein (New York: Signet, 1965), x. All further references will appear in the text.

24. Gilbert and Gubar, The Madwoman in the Attic, 230.

25. Anne K. Mellor, Mary Shelley: Her Life, Her Fictions, HerMonsters (New York: Methuen, 1988), 38. Mellor shows, however, that Percy Shelley undertook considerable stylistic editing, including Frankenstein's much-discussed references to himself as "author" and numerous changes that make Frankenstein appear more sympathetic and the Creature more monstrous. 
form in which it was presented to the world" (xi), possibly at that point buffering Frankenstein's horror story with Walton's relative normalcy.

As an "author," indeed, Walton is to imitation what Frankenstein is to originality. Much as the author of Frankenstein sought to "prove herself" by inscription on "the page of fame" (viii), Walton had hoped to "obtain a niche in the temple where the names of Homer and Shakespeare are consecrated" (16). But he enters this text as a disappointed poet reduced to the (feminine) act of private letters, bearing "heavily" his "failure" to achieve the poetic "paradise" he had sought from childhood (16). It is also as a literary failure that Shelley first represents herself in the preface to Frankenstein: the stories she "scribbled" as a child manifest a "most commonplace style" and imitative content, "rather doing as others had done than putting down the suggestions of my own mind" (vii-viii). When Percy Shelley began urging his wife to write, he did not, she reports, expect her to "produce anything worthy of notice," and when the group made a pact to write ghost stories, Mary Shelley felt only "that blank incapability of invention which is the greatest misery of authorship." Even success would be failure, since the "illustrious poets" Shelley and Byron, "annoyed by the platitude of prose," had already given up the "uncongenial task" of inventing a story's "machinery" (ix). For both Shelley and Walton the solution is Frankenstein, appearing Romantically as the figment of dream. Beholden like Walton to the "unbidden," the daughter of one of the eighteenth-century's most openly autobiographical writers can only claim to record someone else's "infinitely more interesting" tale.

In giving the Creature a voice, however, Shelley undertakes a different kind of authorial project that extricates her from both the unbidden and the imitative: the struggle for an authoritative basisa language, a literary tradition, a credible voice-through which to represent an unauthorized search for subjectivity. Other feminist critics have argued persuasively that this Creature-denied full humanity, lacking history and language, possessed of an "eloquent and persuasive" voice that men are warned not to "trust" (198), naturally gentle but made "monstrous" from misunderstanding and loneliness-is a figure for Woman, hence for Shelley herself. ${ }^{26}$ Although I appreciate

26. See, for example, Ellen Moers, Literary Women (New York: Doubleday, 1976); Gilbert and Gubar, Madwoman in the Attic; and Johnson, "My Monster/My Self." 
the suggestiveness of such readings, it seems to me equally important that materially Shelley's Creature is male, and though it may have been a powerful autobiographical act for her to give him a "feminine" condition and sensibility, female voice and experience (and their particular ways of complicating Romantic "woes" and "wonderful events") are withheld here just as Shelley withheld the "true compositions" of her childhood. Multiply voices as it might, Frankenstein is a story not of female subjectivity but of the impossibility of its transcription: like Frankenstein, Shelley "could not compose a female" (143). In its narrative layering, however, one can see in Frankenstein a progressive movement from passive reception toward unauthorized autonomy, from Mrs. Saville's silence through Walton's imitation, from Frankenstein's brilliant but frighteningly unconventional creation to the self-construction of a subject who cannot be named woman but who also cannot be named man.

Ironically, although this novel may be grappling with autobiographical and authorial dilemmas that surely stem from the difficulties of writing Romanticism as female, in an important sense Shelley's use of male voices serves the cause of women's authority well. Because convention bids her to tell her Romantic story as a male "generic" text, it is through male voices that Shelley writes out her "anxieties of authorship." Had Shelley created women as unsuccessful poets, physical "monsters," or progenitors of the grotesque, her work could not have failed to support the ethos by which female creation is already seen as imitative, distorted, or misguidedly Promethean. Shelley had wanted in her preface to speak about "authorship alone," and to speak of "authorship alone" was to speak of male authorship. Given the conservatism of Romanticism's literary gender roles, it seems to me that to struggle with questions of authority through female voice would call into question not authority but female voice. Thus the Creature's male gender allows it to be a metaphor for, rather than a representation of, a woman: the monster may figure a woman's anguish, but a woman is not a monster.

Read from the evidence of Shelley's next novel, Frankenstein takes on further significance as an elaborate strategy not only for working out authorial anxiety but for working toward female voice. In 1819 the writer who could not "think of a story" created another, more directly autobiographical fiction, which I read as a link between the "feminized" Creature of Frankenstein and Shelley's own history. If Frankenstein uses male voices to write out a gendered anxiety, Mathilda 
uses female voice to write in a gendered history. Whereas Shelley may have created the structure of Frankenstein by adding on layers of male voice, there is clear textual evidence that she created Mathilda by stripping away layers of voice until what remained was the single personal voice I have associated with male Romantic literature. Here, as nowhere else in Romantic fiction, is the female voice that "holds the center" of her text in a plot in which the female body becomes the site of conflict.

Mathilda (like Shelley herself) has lost her mother ten days after birth. Left to the care of a cold and stern Scottish aunt, she grows up desperately lonely, her "warm affections finding no return from any other human heart." Books-mostly the same books (Shelley and) the Creature loved-supply "the place of human intercourse." ${ }^{27}$ Like the Creature, Mathilda longs for fathering; she imagines running away, "disguised like a boy" to "seek my father through the world" (11). Mathilda's father does return when she is sixteen, but the relationship, like that between Frankenstein and the Creature, goes grotesquely awry, for reasons equally corporeal but sexually differentiated. When the father begins to shun his daughter, she presses from him a confession that his love for her is incestuous; he is convinced that her mother's spirit has been "transferred into [Mathilda's] frame, and she ought to be as Diana to me" (40). Mathilda sends him away with "a daughter's curse" and a double message: to "return pure to thy child, who will never love aught but thee" (34). The father commits suicide; Mathilda blames herself; like both Frankenstein and the Creature, for whom "sorrow only increased with knowledge" (Frankenstein 1 15), Mathilda is destroyed by her (Romantic) need to know. The despairing daughter then arranges her own "death" so that she can escape into solitude and await the "eternal mental union" with her father that death alone will provide. After two years of hermitage, as she begins to long for "the love that is the soul of friendship" (53), she meets the poet Woodville, whose history resembles Percy Shelley's and whose poetry holds Mathilda "enchained to his discourses" (61), although until she is dying she cannot bring herself to "give words" to her own "dark tale."

The language of Mathilda is a language of isolation, horror, and anguish whose phraseology strikingly repeats Frankenstein's. In both novels, the monstrosity of a parent begets a "monstrous" child. Like

27. Mary Wollstonecraft Shelley, Mathilda, ed., Elizabeth Nitchie (Chapel Hill: University of North Carolina Press, 1959), 10. All further references will appear in the text. 
Victor Frankenstein, Mathilda's father calls himself a "monster" and a "fallen archangel" (31); like the Creature, Mathilda laments an "eternal barrier between me and my fellow creatures"; she is "struck off from humanity; bearing no affinity to man or woman; a wretch on whom Nature had set her ban" (62), an "outcast from human feeling, this monster with whom none might mingle in conversation and love"; she wonders why fate had not "from that fatal and most accursed moment, shrouded me in thick mists and placed real darkness between me and my fellows so that I might never more be seen" (71), so that "I should have lived upon this dreary heath unvisited, and blasting none by my unhallowed gaze" (72). "I was in truth," she says, "a marked creature, a pariah, only fit for death" (72). The Romantic conflict of the novel is thus the conflict between gendered and generic versions of identity that $I$ have already described in Charrière; Mathilda struggles to be a "transcendent" self, while her father reconstructs her as the object of (his) desire.

The form Shelley ends up creating for this female-centered version of monstrous alienation and failed fathering is a memoir presented, like Frankenstein, as unbidden: Mathilda composes it only when she is "too weak both in body and mind to resist the impulse" to tell. Technically the story is private, directed only to Woodville, but Mathilda, like Mistriss Henley, narrates "as if I wrote for strangers," stretching private voice toward public ends (and thus implausibly telling Woodville his own history). But Shelley did not come immediately to this form: Mathilda began with the framed structure in which Frankenstein ends up. The original version, entitled "The Fields of Fancy" and modeled on Wollstonecraft's unfinished "The Caves of Fancy," creates three narrators who frame one another's texts. Walton's counterpart is a person of unspecified sex who has "suffered a misfortune" that "reduced me to misery \& despair," and who is conducted by a spirit to the Elysian Fields to listen to "the Prophetess Diotima the instructress of Socrates" (94). Among Diotima's disciples is Mathilda, whom Diotima urges to narrate "her earthly history" (102). The unnamed extradiegetic narrator thus becomes the scribe of both Diotima's wisdom and Mathilda's tale, so that structurally as well as psychically, Mathilda occupies the Creature's place in a narrative whose three voices may well be female.

In revising Mathilda, however, Shelley removed the buffers of setting and form that distance Mathilda's narrative, leaving a novel written wholly in a single, female voice. Devon Hodges had suggested on 
the basis of Frankenstein that for Shelley the singular "I" is a "unifying device that needs transformation if women are to speak"; ${ }^{28}$ Mathilda suggests that it is not singular voice but male voice that Shelley needed to transform. When, in Mathilda, Shelley does "compose a female," she strips away the layers of narration built around the equivalent voice in Frankenstein.

It is impossible to know whether the fate of this novel might have been different had Shelley kept the original, buffered structure of "The Fields of Fancy." Contrary to Shelley's proclaimed intentions, Mathilda, arguably the creature-text "ten thousand times more malignant than her mate" (Frankenstein, 158), was never published during her lifetime. It is a powerful and disturbing irony that Shelley put the fate of this manuscript in her own father's hands. As she would later do with Valperga, which she also wrote in Italy, Shelley gave her fair copy of Mathilda in May 1820 to her friends the Gisbornes, who were returning to England, asking them to deliver it to Godwin so that he could find it a publisher. As Elizabeth Nitchie reports, there is "no record of his having made any attempt to get it into print," and Shelley apparently tried repeatedly through Maria Gisborne to get the manuscript returned to her; the completed novel turned up only after Shelley's death. While the Gisbornes strongly admired Mathilda, Godwin apparently considered it uneven in quality and "disgusting and detestable" in subject. ${ }^{29}$ Surely a complex psychic history is buried in the saga of this novel's composition, Shelley's decision to send it to Godwin, and Godwin's (non)response.

I would like to read the fate of Mathilda, however, as more than an accident of biography. In an important sense, it is fitting that Shelley sent Mathilda to Godwin rather than directly to a publisher, for this gesture repeats Mathilda's own self-destructively tenacious subordination to a man who cannot allow his daughter her individuality. In this sense, Mathilda is as much Romantic heroine as Romantic hero; she embodies the spirit of superior sensitivity and genius, alienation, and longings for transcendence, but she cannot untangle these longings from her desire for the father who torments her. While the Creature blamed its father, Mathilda blames herself, and because she

28. Hodges, "Frankenstein and Feminine Subversion," 157.

29. See Nitchie, introduction to Mathilda, xi; and Mary Shelley's letters of 9 February 1822 , 7 March 1822, 10 April 1822, and 2 June 1822, in The Letters of Mary Wollstonecraft Shelley, ed. Betty T. Bennett, vol. I (Baltimore: Johns Hopkins University Press, 1980). See my Chapter 12 for the similarly negative language Godwin will use to describe the unfinished section of Wollstonecraft's The Wrongs of Woman. 
continues to hold herself responsible for his death and to desire no other love, she remains not only the victim of the patriarch but his loyal subject as well. It seems likely that Godwin's censorship would have been re-enacted by a publisher; even Frankenstein was rejected by several presses before Lackington accepted it in 1817 . Godwin's refusal to return Mathilda suggests the dangers female voice poses when it turns the tables on male Romantic subjectivity. Shelley apparently never confronted her father directly about this manuscript, and she did not write another novel in a female personal voice.

George Sand's Lélia (1 833) reveals the dissonance between Romantic representation and Romantic subjectivity from virtually the opposite stance; its project is precisely the refusal to reduce desire to the gendered shape that even Corinne and Mathilda give it. Ellen Moers exults that Lélia "claim[s] all of Romanticism for women," "tak[ing] her place beside Werther, René, Obermann, Childe Harold, Adolphe, Alastor, Raphaël de Valentin and the rest of the swollen masculine egos of the age. Lélia feels the guilts, the aspirations, the alienation, the boredom, the sterility, the pride, the rebelliousness of the Romantic hero; she plays the cold dandy, the demon lover, the inspired prophet, the doomed soul-and remains all Woman." 30 Although Sand is able to make Lélia the center of the plot, however, she does not make her the novel's single voice. Instead, if one agenda of Lélia is to fulfill Staël's proclamation that genius has no sex, the novel's form dramatizes as an impossible fiction that a woman is as free as a man to express this genius.

Lélia's central conflict concerns the challenge to Lélia's reserve by Sténio, a young poet who loves her passionately at a time when a tormenting and oppressive affair has left her sexually impotent and when she has wearied of ever reaching the transcendent understandings to which she aspires. On guard against the reduction of woman to Romantic object yet on the verge of yielding to Sténio, Lélia fears that "it's scarcely a soul you want: it's a woman, isn't it?" (142), and sends her courtesan sister Pulchérie in her place. The "Lélia" to whom Sténio makes love-vowing that he has never loved more deeply-is thus actually Pulchérie (a hoax the text also perpetrates upon the reader). When the truth is revealed, Sténio turns in despair to de-

3o. Moers, Literary Women, 201 ; Moers, foreword to Lélia, trans. Maria Espinosa (Bloomington: Indiana University Press, 1978), vii. Citations of Lélia are from this edition and will appear in the text. 
bauchery, and even the efforts of their aging and ascetic friend, the reformed gambler Trenmor, do not save Sténio from suicide. Lélia herself dies a violent death that, once again, is inseparable from her sex: she is strangled with a rosary by Magnus, the Irish priest whose tormented passion for her has finally driven him insane.

In form Lélia is a pastiche of letters, authorial narration, interior monologues, and dialogues among all the major characters. Often the identities of a narrator and narratee must be inferred; it is not always certain whether a narrator is writing or speaking; and nearly all markers of time and place have disappeared. Lélia's "shapelessness" has led many critics to consider it an aesthetic failure; even its English translator says that perhaps it "should not be judged as a 'novel' in modern terms" (xx). Eileen Boyd Sivert has argued that, on the contrary, the formal eclecticism of Lélia functions subversively as a refusal of patriarchal constraints: "Sand's discourse, which offers so many ways of approaching woman's story, does not enclose or smother, it is strikingly open, loose, plural." For Sivert the text's narrative openness gives Lélia "a freedom of movement in narration which contrasts sharply with her position in society." In the novel's multiplicity of narrators, Sivert sees a challenge to "exclusive, appropriating narrative authority" and a willingness on Lélia's part to "admit the 'other' into a kind of shared writing without losing control over the recounting of herself. Having no voice in society, Lélia can be heard in narration, in what slips out of the norm, out of the dominant (masculine) discourse, in what can only be 'got at' sideways, in the margins, the gaps or breaks, and silences in the text." 11

But this valorization of pluralism denies the struggle for subjectivity that constitutes Lélia's central quest. I see the form of Lélia not as a flight from social constraints but as their necessary inscription. The novel's complicated, unpredictable narrative structure replicates the unpredictable and complicated contestations over Lélia's identity, which can never settle into that of "generic" poet because she is never free from the projections and the desires of men. As she says to Pulchérie, "To be lover, courtesan, and mother... These are the three conditions of a woman's fate which no woman escapes" (100). If Lélia's is the text's dominant personal voice, it is the voice almost always

31. Eileen Boyd Sivert, "Lélia and Feminism," Yale French Studies 62 (1981): 47, 48, 64. I do not understand the suggestion that Lélia is "sharing" narrative voice, since the text is not structured as "hers." Such a decision would have to be Sand's, or Sand's authorial narrator's, not Lélia's. 
responding to other voices; we first see her through male eyes just as we see nearly all Romantic women from Werther's Charlotte to Oswald's Corinne to Victor's Elizabeth. The novel opens precisely with Sténio's question to Lélia, "Qui t'es- tu?"-"Who are you?"-and with his refusal to accept Lélia's insistence that they are "brothers" (7), that "my soul is the sister of yours" (8). Even the wise Trenmor, who counters Sténio's insistence that "where there is no love, there is no woman" by asking him whether he believed "that where there is no love, there is no man" (30), and who places Lélia in a noble bisexual tradition that includes Galatea, Tasso, Dante, Romeo, Hamlet, Juliet, Lara, and Corinne, imposes gender when he accuses Lélia of having "a woman's ferocious ingratitude and vanity" (32) and appeals to her to "mother" Sténio (33). And Magnus's projection upon her of the "double" (52) who is both angel and demon, spirit and flesh, will literally be the death of her. Lélia's silencing by strangulation occurs precisely because she refuses Magnus's demands to "console me. Love me" (227), and provides fitting closure for a text in which a female voice that "holds the center" would have produced a false representation of Lélia's autonomy.

For all her greatness, Lélia cannot escape being defined from the outside, and it is the struggle within and against such definitions that I believe the narrative form of Lélia represents. The men's constructions of Lélia, juxtaposed to Lélia's version of herself, suggest that to allow the female Romantic figure a central or exclusive voice is to perpetuate the illusion that woman can simply constitute her self as generically human and have that construction accepted alongside Goethe's construction of Werther or (Sand's lover) Musset's of Octave. Instead, Lélia's form juxtaposes Lélia's complex subjectivity to the versions of the men who project upon her the shapes of their desires. It is significant that Lélia's deepest secrets are told only to Pulchérie: at the heart of the novel, where Corinne tells her story to Oswald, Lélia tells hers to her sister.

Given the equation between women writers and their first-person subjects that I have suggested in Chapter 8, it is also likely that Sand's reputation could not have sustained the autobiographical implications that a wholly autodiogetic version of Lélia would have produced. As it was, Lélia's feminization of Romantic codes turned against Sand; she suffered "emotional agony and personal humiliation" for publishing this book, which was easily the most controversial novel of its 
day, ${ }^{32}$ and she even attempted to replace the original with a toneddown version in 1839 - the only substantial revision of a novel that she ever undertook. Although the revised version never caught on, and Lélia remained both controversial and widely admired, it is ironically appropriate that the novel that now represents a woman's Romantic "masterpiece" (after its own long-standing trivialization and neglect) is the male-dominated Frankenstein.

I stated earlier that women faced two challenges if they were to write Romantic fiction: to displace the male subject and hence male voice as textual center, and to re-present Romantic tropes in female terms. Novels such as Caliste, Corinne, Mathilda, and especially Lélia suggest that it was possible to construct a female character with Romantic desires and conflicts while also showing the tension between "femininity" and humanity. The second challenge, displacing the male subject as the narrative center, clearly proved more difficult. I see no evidence that Romantic women refused personal voice in virtuous avoidance or deconstruction of hegemonic subjectivity. Rather, I see in the complexity of women's Romantic fictions the sign that if Romantic genius was generically "human," its narrative expression was still a matter of sex.

32. Joseph Barry, "George Sand: Our Existential Contemporary," in The George Sand Papers (New York: AMS Press, 1980), 19. 